\section{DESIGN MANAGEMENT CAPABILITY ASSESSMENT FROM THE PERSPECTIVE OF COMPANIES PURSUING DIFFERENT BUSINESS STRATEGIES IN GLOBAL VALUE CHAINS (1)}

Bilgen TUNCER MANZAKOĞLU*, Özlem ER**
Received: 12.05.2021; Final Text: 31.12.2021

Keywords: Design management capability; functional upgrading; latecomer firms; global value chains; business strategy.

1. This article is based on the PhD Thesis of Bilgen Tuncer Manzakoğlu (Manzakoğlu, 2018).

\footnotetext{
* Department of Industrial Design, Bahçeşehir University, Istanbul, Turkey

${ }^{* *}$ Department of Industrial Design, Bilgi University, Istanbul, Turkey.
}

\section{INTRODUCTION}

The role of design in business has long been a subject of discussion in a multitude of academic studies (Kotler and Rath, 1984; Walsh et. al., 1992; Dippolito, 2014). Since design management (DM) can be used at different levels within an organization, various forms of audits (Design Council, 1999; EFQM, 1995; Kotler and Rath, 1984), assessment tools, ladders (Danish Business Authority, 2008; Kootstra, 2009; Westcott et al., 2014), checklists, conceptual frameworks (Topalian, 1990; Cooper and Press, 1995; Chung, 1998) and models (Storvang et al., 2014) have been developed by researchers or organizations to facilitate the integration of design into business strategy and to assess the level of DM and its related aspects. These, however, do not have a particular focus on DM capability in relation to the business strategies pursued by companies operating in emerging economies to take a position in global value chains (GVCs).

Despite the existence of several studies exploring design as part of a broader capability development process and emphasizing the linkage between business and design strategies (Mutanen, 2008; Acklin, 2013), there is a general lack of focus in the DM literature on GVC-oriented industrialization. Indeed, in an earlier article, we have emphasized that the existing DM frameworks and studies do not address the particular industrial development paths and capability-building strategies followed by LCFs in GVCs (Manzakoğlu and Er, 2018).

Thus, we put forward a new framework under the title of Design Management Capability Framework in GVCs (Figure 1) to build linkages between OEM-ODM-OBM business strategies in GVCs and DM capability at three levels: operational, functional, and strategic.

Companies from emerging economies were defined as latecomer firms (LCFs) since they are operating outside of the world's innovation centers and lack technology and market access (Hobday, 1995). While 


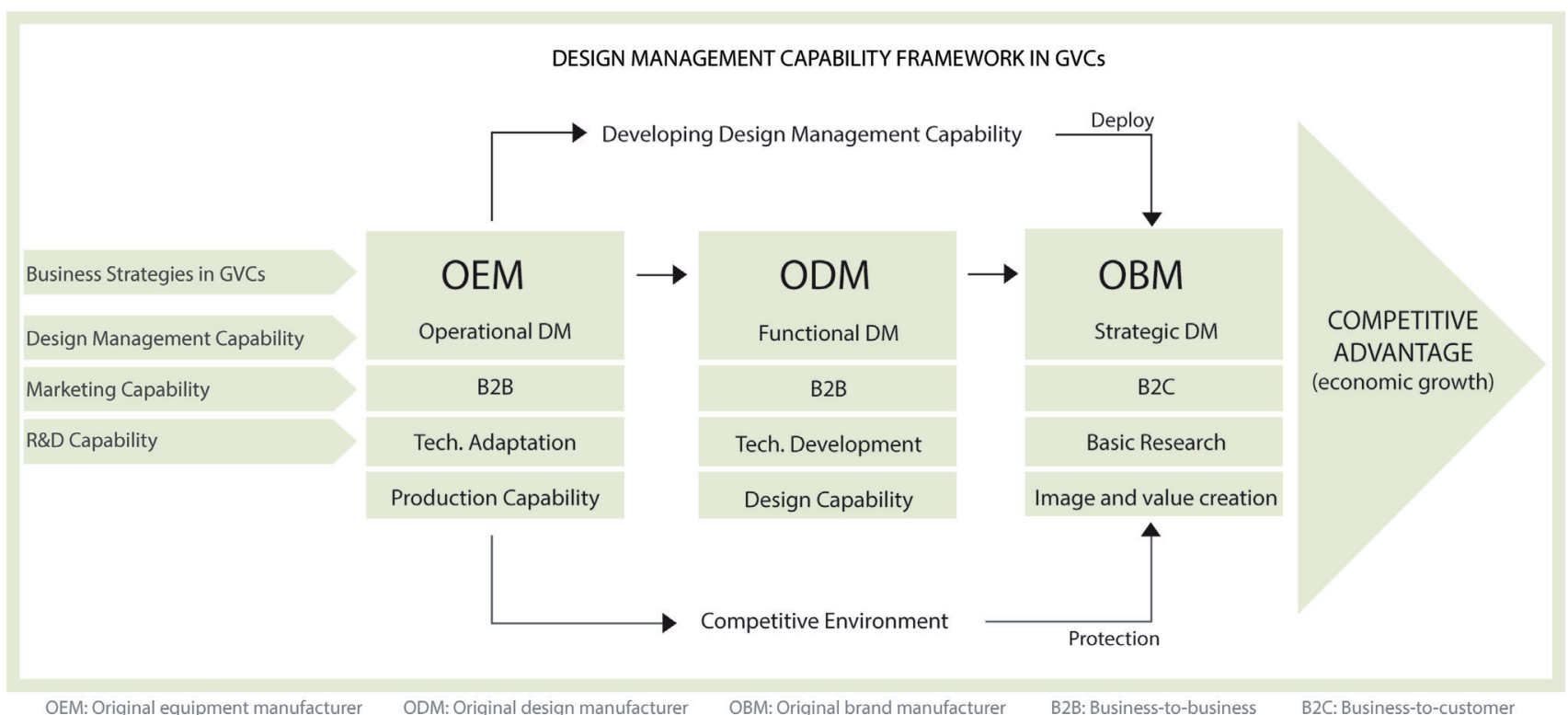

Figure 1. Design management capability framework in GVCs (Manzakoğlu, 2018). innovation/upgrading capability of latecomers in GVCs has been affected by institutional context, geographical consideration, entire input-output process, and governance power of lead company(s) on the entire network (Gereffi and Fernandez-Stark, 2011), they can achieve four types of upgrading including process, product, functional and chain/inter-sectorial upgrading (Humphrey and Schmidt, 2002). Functional upgrading is significant and necessitates adding new functions to business beginning with Original Equipment Manufacturer (OEM) strategy which entails economies of scale manufacturing, export activities, advanced production capabilities, and assembly of standard simple goods for global brand owner companies or original brand manufacturers (OBMs), followed by adding design function to upgrade to the Original Design Manufacturer (ODM) position which embraces designers, detailed industrial design activities, etc. and finally structuring their marketing and sales function to become an OBM which stands at the top of the value chain (HKTDC, 2008; Hobday, 1995). Although this paper focuses on investigating the features of different DM capability levels in functional upgrading, it also aims to explore the types of upgrading targeted in pursuing OEM-ODM-OBM business strategies. OEM/ODM are business-to-business (B2B) models in which LCFs manufacture and design their products for globally known OBMs. In the GVCs literature, however, there is no significant reference to DM, and product design is mainly referred to, as part of technological capabilities required to upgrade in GVCs.

OEM companies use DM at the operational level for reducing product parts, aesthetics, or adaptation of products to local markets mainly to improve their manufacturing capability (Manzakoğlu and Er, 2018). In ODM business, design function has a defined role and involves industrial designers, design process, concept development, process innovation, following trends, allocating resources for design activities, managing intellectual property rights, and adequate computer systems to realize technological applications (HKTDC, 2008). Re-organization of design activities in relation to business development creates the strategic DM capability for the upgrading trajectory towards brand ownership. 
Controlling the value chain, the OBM position on the other hand bears more risks while requiring brand building, strategic DM capability, sales and distribution channels, quality image, and unique value. Having explained the features of different DM capabilities in OEM-ODM-OBM strategies based on literature review (Manzakoğlu and Er, 2018), in this paper, we aim to provide case-based evidence of their nature at different DM capability levels in LCFs following OEM, ODM, and OBM business strategies, respectively.

In fact, DM is a critical capability building and organizational learning process for LCFs. Though limited in numbers, several studies were conducted on DM recognized it as an organizational capability (Acklin, 2013; Fernandez Mesa et al., 2013; Santos et al., 2018). According to Acklin, $(2013,149)$ "DM capabilities are the capacity to deploy design resources in an adequate (and dynamic) way" and "to qualify DM as a capability, the capacity to execute a specific task needs to have a patterned element, a company needs to be able to repeatedly perform a certain task". Santos et al. (2018) identify that DM can be a dynamic capability if the following are integrated; design learning corresponding to the skills of acquiring knowledge and practices and spreading them throughout the organization, design coordination corresponding to the capability to coordinate the activities and practices across different functions within the organization, and design skills harbouring a set of techniques and knowledge that generate synergy, creativity, and innovation. Based on these definitions, it can be concluded that managing design skills, processes, and resources in coordination with other functions repetitively and systematically make DM a capability in an organization to achieve innovation.

Considering the fields of inquiry under the DM capability, the categories of the Design Capacity Model (Storvang et al., 2014) were found useful for constituting a protocol for testing the features of DM capability in companies as the model covers most of its identified aspects such as design awareness, design capability, innovation drivers, the importance of design in internal processes, and user's involvement.

In the Design Capacity Model, design awareness indicates the level of openness towards design and acquiring new knowledge. Since design thinking is a collective phenomenon, deploying design in the organization is related to the distribution of design awareness among members of management and staff of the company. In the model, design awareness is explained from bottom to high level as follows: design can be seen as a possibility, design is in top management's agenda, design is present in specific departments, all employees see design as an important factor (Storvang et al., 2014). On the other hand, Design Atlas (Design Council, 1999) put forward a structured audit tool to investigate the design capabilities of companies under five categories. Planning and culture for design categories reflect the design awareness of a company and include seven questions that can be used to search the effectiveness of the business at planning all its activities, the level of communication between staff, the position of design in the overall business plans, and the structured thinking in developing design plans. Each question has a structured answer with several options to choose from that are graded from Level 1 to 4 . Hence, we used the Design Atlas questions to get more detail about design thinkers and how design is planned within the selected companies, and then depending on the answers we determined their levels in planning for design and culture for design categories. 
Figure 2. DM capability categories used in the design protocol.
In the Design Capacity Model, the design capability category corresponds to the design skills whether there are in-house designers or external designers, or both in an organization; innovation drivers address the triggers of the design process in terms of technology, suppliers, market, or design; and user involvement addresses the existence of user research methods comprising surveys and feedbacks, focus groups and observations, co-creations with lead users, and management of user research across functions in an organization (Storvang et al. 2014). User research is a significant phase of the design process through which products, services, or experiences can successfully meet user needs in the target markets.

The importance of design in the internal processes category aims to identify where design is most important in an organization such as at operational (product development, styling), organizational (marketing, production), or corporate levels (innovation, strategy, and management). However, DM capability can be better understood by investigating the management of change, design, and cross-functional teams (organizational level) and how corporate values and project value is aligned to create a coherent customer experience in detail (corporate level) (Acklin 2013). Hence, we extended the importance of design in the internal processes category to the three-level DM assessment, checking DM at the project (operational), organizational (tactical), and corporate levels (strategic) based on Chung's categorization (1998).

Design Management Capability Framework in GVCs also encompasses marketing and technological capability as required capacity building fields in addition to DM capability. Marketing capability is critical for companies in reaching target customers with value-added products and services by applying collective knowledge and skills in the integrative processes, especially at the product development stage where consumer needs and competition must be assessed (Weerawardena, 2003). Additionally,

DESIGN MANAGEMENT CAPABILITY FRAMEWORK IN GVCS

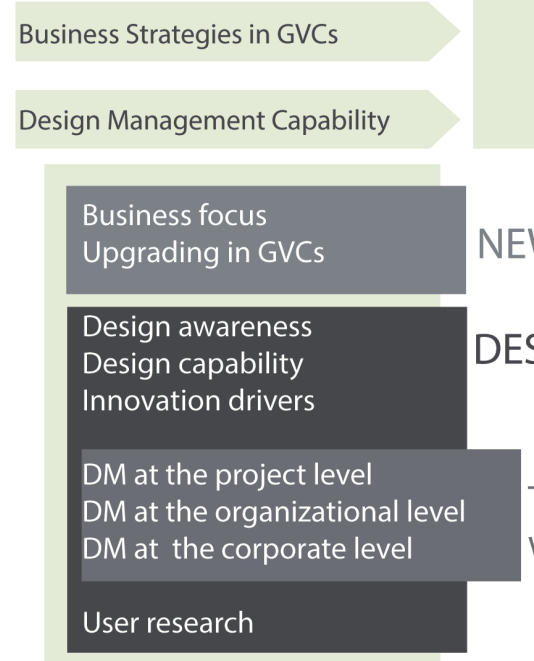

OEM

Operational DM
ODM

Functional DM
OBM

Strategic DM

\section{NEW CATEGORIES emerged after case studies}

\section{DESIGN CAPACITY MODEL CATEGORIES}

THE IMPORTANCE OF DESIGN IN INTERNAL PROCESSES CATEGORY was checked at project, organizational and coporate levels.

Marketing Capability

R\&D Capability
B2B

Tech. Adaptation
B2B

Tech. Development
B2C

Basic Research 
technological capability is significant for product innovation by investing in R\&D capability for the accumulation of technological knowledge (Afuah, 2002).

The framework was used as a basis of inquiry and revised through the empirical data obtained via three case studies undertaken in companies pursuing OEM-ODM-OBM strategies in Turkey as an emerging economy. As the literature on DM does not focus on the gradual development patterns of latecomers in GVCs and does not differentiate DM as a separate capability within the range of technological and marketing capabilities required by LCFs to upgrade in the global trade, this article explores how DM capability differs across OEM-ODM-OBM business strategies.

\section{RESEARCH DESIGN AND METHODS}

The case study method is particularly useful in gaining insight into the holistic characteristic of real-life contexts such as organizational and managerial processes (Yin, 2014) and in understanding the theoretical linkages in more detail (Easton, 2010). Following the theoretical conception of the Design Management Capability Framework in GVCs, explanatory and descriptive case studies were conducted to explore the nature of DM capability in relation to OEM-ODM-OBM business strategies and, also testing and adding flesh to the theoretical framework. According to the literature, latecomer firms begin to use design under OEM business strategy to achieve export activities, develop production capabilities, and assembly of standard simple goods for global brand owner companies (Hobday, 1995; Ernst, 2008). In the selection of the sector and particular companies to focus on, we identified the main criteria as to be following OEM-ODM-OBM strategies, large-scale exporting for global brands, and manufacturing final goods rather than components. Although the key sectors for conducting case studies on GVCs were defined as consumer durable goods, electronics, automotive, textile, and apparel (Gereffi and Sturgeon, 2013); in Turkey, the most convenient sector for this research was identified as the electrical and electronics industry According to OECD (2012), electronics is the industry where GVCs are the most pervasive. In Turkey, the electrical and electronics industry, with its subsectors of electronics, white goods and small appliances, electrical machinery and equipment, has played an important role in competing with global companies in international markets (Taymaz and Yilmaz 2008) with the export rate of $8.6 \%$ (\$10.5 million in \$121 million) of the manufacturing industry (Turkish Exporters Assembly 2016). The export data indicate that Vestel, Arçelik (which merged with Beko in 2008), and Termikel are the leading producers in the electronics and white goods sector with the export rates of $\$ 2.00$ million, $\$ 1.77$ million, and $\$ 0.31$ million, respectively (TIM, 2016).

These three firms operating in the electrical and electronics industry, documented in their annual reports, websites, and research articles as pursuing OEM-ODM-OBM strategies in the local and global markets were specifically selected. The selection criteria focused on the business strategies adopted by these companies to position themselves in GVCs, not on the ones pursued in the Turkish domestic market. The cases representing ODM (Vestel) and OBM (Arçelik) business strategy implementation in our sample are in fact unique cases in the sense that there are no comparable companies in the Turkish electronics industry in terms of their sizes, scope of manufacturing, and large-scale exporting. 


\begin{tabular}{|c|c|c|}
\hline Category & Content of each category & Questions \\
\hline Design awareness & $\begin{array}{l}\text { Design awareness questions aim to reveal the } \\
\text { design thinkers within an organization (no one, top management, a } \\
\text { department, all the employees). } \\
\text { We used Design Atlas' themes to get more detail: the effectiveness } \\
\text { of the business at planning all its activities, the level of } \\
\text { communication between staff, the position of design in the overall } \\
\text { business plans, the structured thinking in developing design plans. }\end{array}$ & $\begin{array}{l}\text { The planning and culture for design } \\
\text { audit questions of the Design Atlas } \\
\text { (Design Council, 1999) were asked. } \\
\text { Structured questions have Likert } \\
\text { scale answers: } 1-4 \text {. }\end{array}$ \\
\hline Design capability & $\begin{array}{l}\text { Numbers and backgrounds of designers (internal, external, or } \\
\text { both), } \\
\text { developmental phases/history of design in line with the } \\
\text { development of business strategy in GVCs were questioned. }\end{array}$ & Open-ended questions were asked. \\
\hline Innovation drivers & $\begin{array}{l}\text { The main driver of innovation was searched in terms of technology, } \\
\text { suppliers, market, or design }\end{array}$ & Open-ended questions were asked. \\
\hline $\begin{array}{l}\text { DM at the project } \\
\text { level }\end{array}$ & $\begin{array}{l}\text { Triggers of a design project, the role designers in new product } \\
\text { development (NPD), the difference between design projects across } \\
\text { OEM-ODM-OBM strategies were searched. }\end{array}$ & Open-ended questions were asked. \\
\hline $\begin{array}{l}\text { DM at the } \\
\text { organizational level }\end{array}$ & $\begin{array}{l}\text { Organizational scheme and processes, integration of design into } \\
\text { organizational processes, coordination, and scope of design } \\
\text { processes were investigated. }\end{array}$ & Open-ended questions were asked. \\
\hline $\begin{array}{l}\text { DM at the corporate } \\
\text { level }\end{array}$ & $\begin{array}{l}\text { DM responsibility at the top management level, design strategy, } \\
\text { the role of design in the brand building were investigated. }\end{array}$ & Open-ended questions were asked. \\
\hline User research & $\begin{array}{l}\text { The management of user research in the organization, methods } \\
\text { used in user research, and the difference of user research between } \\
\text { OEM-ODM-OBM strategies and were investigated. }\end{array}$ & Open-ended questions were asked. \\
\hline
\end{tabular}

Table 1. Case study protocol contained questions to inquire about the issues as indicated in Figure 2.
Thus, we based our selection of companies on theoretical sampling. By adopting similar selection criteria, this study can be repeated across different sectors and in other emerging countries.

Looking closely at the companies in the sample, it is noted that the main focus of Vestel is the electronics sector, whereas Arçelik (Beko) and Termikel mainly focus on white goods. While Arçelik has been following OBM strategy in the global and local market, Vestel has adopted a dual strategy - OBM in the local and ODM in the global market - and Termikel has been pursuing a predominantly OEM strategy both locally and globally.

The process of inquiry and systematic data collection were organized through a case study protocol (Yin, 2014), designed to collect data under the guidance of the conceptual framework as mentioned indicated in Figure 2 and explained in Table $\mathbf{1}$.

Using a case study protocol and case study database as suggested by Yin (2014) contributed to maintaining reliability and enabled the triangulation of data obtained from a variety of resources such as interviews, business reports, company documents (e-mailed to the researcher), scientific and newspaper articles, magazines, books, and official company websites.

The primary data were gathered from semi-structured interviews with key informants, employees of ID, marketing, and R\&D departments of each company (Table 2). Considering DM capability as an organizational capability necessitated questioning the R\&D and marketing managers to explore how innovation, user research, and coordination between functions and cross-functional teams were managed.

All of the interviews were conducted face-to-face, recorded, and transcribed fully. Data collected from primary and secondary sources 
Table 2. Interviewee details of Termikel, Vestel and Arçelik.

\begin{tabular}{|c|c|c|}
\hline Termikel Interviews & Duration & Date \\
\hline GM Assistant & $60 \mathrm{~min}$. & 3.05 .2016 \\
\hline Marketing Manager & $90 \mathrm{~min}$. & 3.05 .2016 \\
\hline Hood R\&D Manager & $60 \mathrm{~min}$. & 3.05 .2016 \\
\hline Oven R\&D Manager & $45 \mathrm{~min}$. & 3.05 .2016 \\
\hline \multicolumn{3}{|l|}{ Vestel Interviews } \\
\hline $\begin{array}{l}\text { Marketing, GM (General Manager) Assistant } \\
\text { Marketing, TV Brand Manager }\end{array}$ & $70 \mathrm{~min}$. & 15.01 .2016 \\
\hline $\begin{array}{l}\text { Vestel Electronics, ID (Industrial Design) Manager } \\
\text { Vestel Electronics, Senior Industrial Designer }\end{array}$ & $\begin{array}{l}130 \mathrm{~min} . \\
50 \mathrm{~min} .\end{array}$ & 7.03 .2016 \\
\hline Vestel Electronics R\&D GM Assistant & $50 \mathrm{~min}$. & 7.03 .2016 \\
\hline $\begin{array}{l}\text { Vestel White Goods, ID Manager } \\
\text { Vestel White Goods, Industrial Designer }\end{array}$ & $120 \mathrm{~min}$. & 7.03 .2016 \\
\hline \multicolumn{3}{|l|}{ Arçelik Interviews } \\
\hline ID Director & $120 \mathrm{~min}$. & 31.03.2016 \\
\hline Senior Industrial Designer & $80 \mathrm{~min}$. & 28.04.2016 \\
\hline Product Sourcing R\&D Manager & $90 \mathrm{~min}$. & 28.04 .2016 \\
\hline Small Appliances Marketing Manager & $110 \mathrm{~min}$. & 9.05 .2016 \\
\hline \multicolumn{3}{|l|}{ Phone-call interviews with previous Arçelik employees } \\
\hline ID Manager, 1988-2002 & $25 \mathrm{~min}$. & 16.06 .2016 \\
\hline Industrial Designer, 1991-2002 & $15 \mathrm{~min}$. & 15.06 .2016 \\
\hline Industrial Designer, 1993-2007 & 20 min. & 15.06.2016 \\
\hline Beko, ID Manager, 2002-2008 & $25 \mathrm{~min}$. & 16.06 .2016 \\
\hline Beko, Industrial Designer, 2002-2006 & $15 \mathrm{~min}$. & 15.06 .2016 \\
\hline
\end{tabular}

were classified according to the categories in the case study protocol and individual case study reports were written through an iterative process. In addition to the categories in the protocol, barriers to DM capability were explained at the end of the discussion section, but this category was not involved in the guideline table since it is not considered as a field of inquiry for DM capability.

Following the analysis of data from each case one by one, a cross-case analysis was undertaken (Yin, 2014) to describe the similarities and differences between the levels of DM capabilities in pursuing OEMODM-OBM strategies. The synthesis process focused on describing the specifications of each DM capability level in detail. A list of interviewees with dates is given in Table 2.

\section{FINDINGS ON DESIGN MANAGEMENT CAPABILITY LEVELS CORRESPONDING WITH OEM-ODM-OBM BUSINESS STRATEGIES}

This section summarises the main findings of each case study.

\section{Termikel Case - Focus on OEM Strategy}

Termikel is established in 1950 as a subsidiary of a business group. The company has been manufacturing solo ovens, built-in ovens, microwave ovens, mini ovens, hoods, hobs, built-in hobs, and dishwashers. It pursues OEM strategy in GVCs and OBM strategy in the local market. It has been an OEM to 111 brands such as Franke, Silverline, Bosch, Siemens, Ariston, and Argos (75\% of its production), and OBM with its own brands (25\% of its production) (Oven R\&D Manager 2016; GM Assisstant, 2016). 


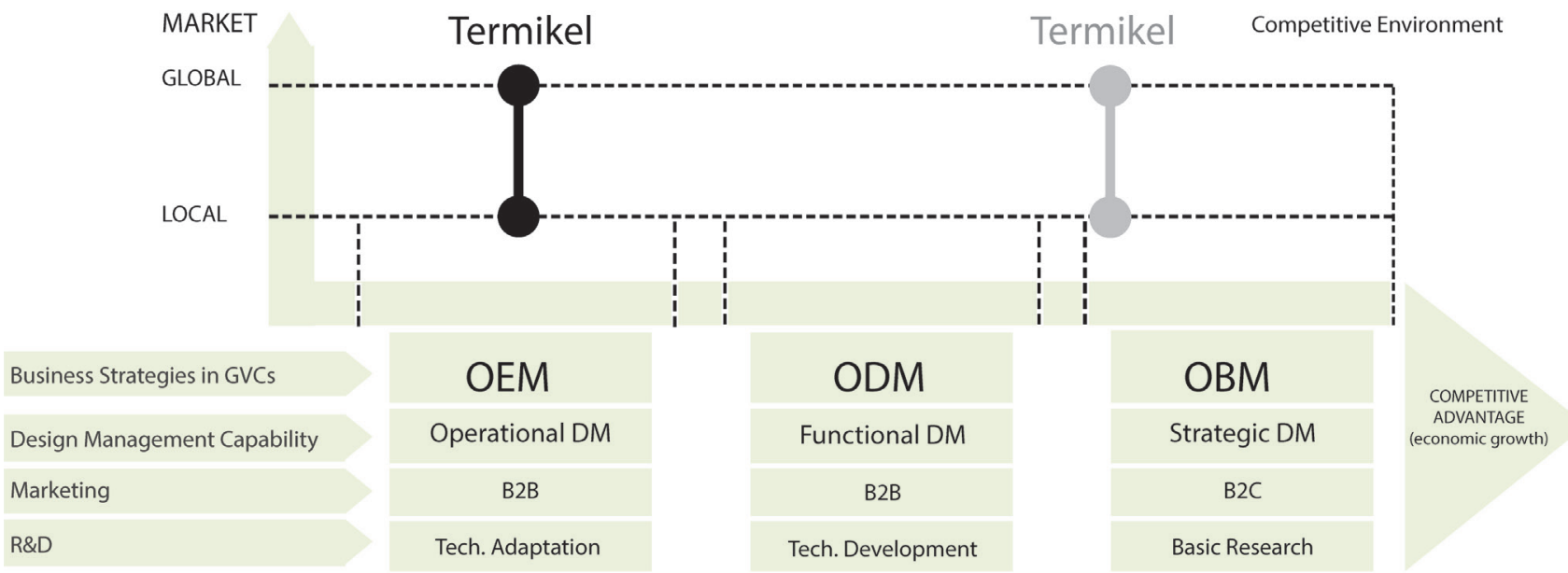

Figure 3. DM capability level of Termikel.

Figure 4. DM capability level of Vestel.
The operational DM capability of Termikel as an OEM is shown in the framework (Figure 3).

\section{Vestel Case - Focus on ODM Strategy}

Vestel is established in 1983 as a subsidiary of a business group. While Vestel Electronics (VE) performs $60 \%$ of its production and Vestel White Goods (VBE) performs 40\% (Vestel Yatırımcı İlişkileri, 2016). The company has been manufacturing TVs and many products under the electronics and white goods categories.

Vestel pursues OEM-ODM strategies in global markets for brands such as Toshiba, Philips, Sharp, Sony, Sanyo, Hitachi, Schneider, and JVC; and OBM in local and regional markets with its own brands such as FinluxLuxor in Scandinavia and North Europe, Sharp in the Far East, Velfrost in Europe and Russia, Telefunken in Spain, Italy and Portugal, Elektra-Servis-

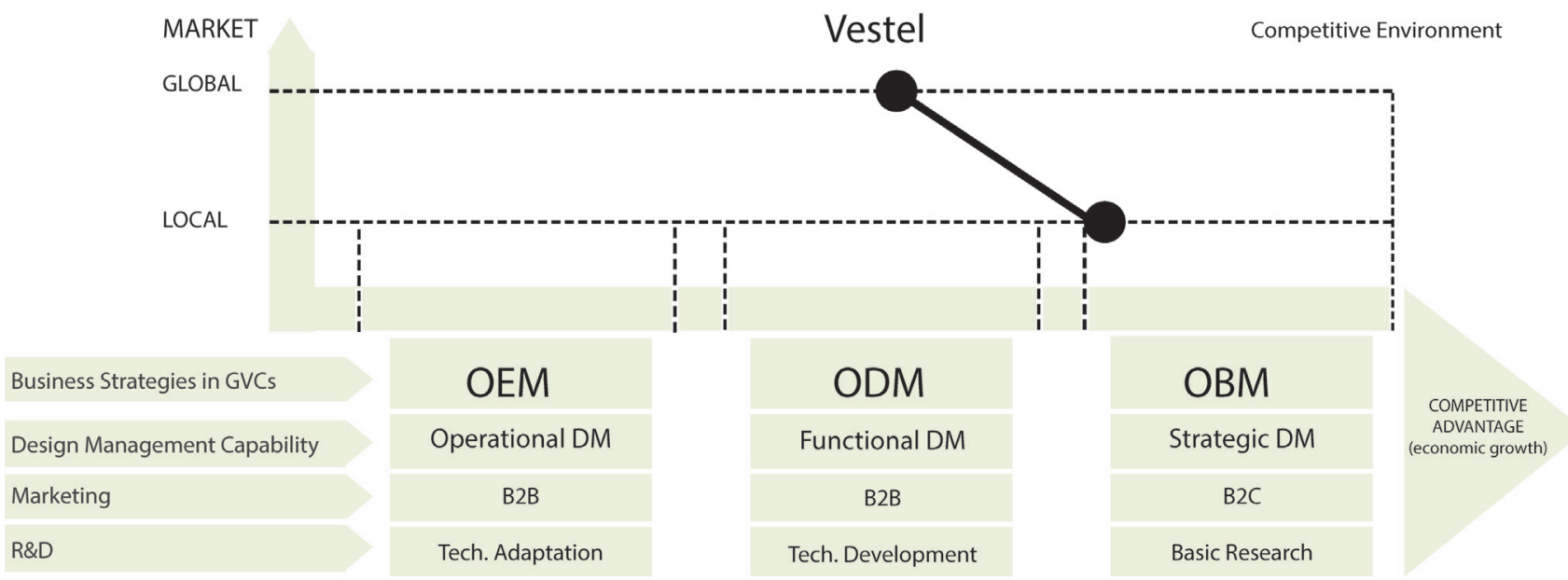


2. CIS Countries are Azerbaijan, Armenia, Belarus, Georgia, Kazakhstan, Kyrgyzstan, Moldova, Russia, Tajikistan, Turkmenistan, Uzbekistan, and Ukraine.
Figure 5. DM capability level of Arçelik.
NewPol-Atlantic in Europe, Teletech in England, and Vestel in Turkey, the Commonwealth of Independent States (CIS) (2) and the Middle East.

Vestel is shown on the framework (Figure 4).

\section{Arçelik Case - Focus on OBM Strategy}

Arçelik is established in 1955 as a subsidiary of a business group. The business group established a separate company (Beko) to produce electronics products for export markets in 1963. This company was merged with Arçelik in 2008. Arçelik transferred know-how and technology between 1955-1990 and manufactured white goods under the licenses of global OBMs such as General Electric and Bosch (Sugur and Nichols, 2005). Document analysis and phone interviews (Table 2) with former employees revealed the upgrading path of Arçelik and Beko. Consequently, Beko was identified as having exploited DM in line with OEM-ODM-OBM export strategies between 1963-2007, whereas Arçelik solely pursued OEM in the 1990s and upgraded directly to OBM strategy in the global market.

Arçelik has been manufacturing white goods (73.2\% of its production), consumer electronics (13.1\% of its production), and other products $(13.7 \%$ of its production) (Arçelik Global, 2016). The company pursues OBM strategy in local and global markets with its own brands. In the multibrand strategy of Arçelik; Beko and Grundig are positioned as global brands whereas Arçelik, Blomberg, Elektrabregenz, Arctic, Leisure, Flavel, Defy, Altus, and Dawlance are positioned as local or regional brands. The core values of Arçelik's corporate culture are innovation and employee engagement.

The current DM capability level of Arçelik and former strategies are shown in Figure 5.

Findings of the case studies indicate that the functional upgrading trajectory to OBM strategy in GVCs is more complicated than the linear upgrading path anticipated in the first theoretical framework (Figure 1). The ODM (Vestel) case showed that an LCF can pursue a dual business strategy simultaneously or jump directly from OEM to OBM (Arçelik), skipping the ODM strategy in GVCs. The different business strategies followed by a company in the local and global markets are shown as black

DESIGN MANAGEMENT CAPABILITY FRAMEWORK IN GVCS

1990s Early 2000s Competitive

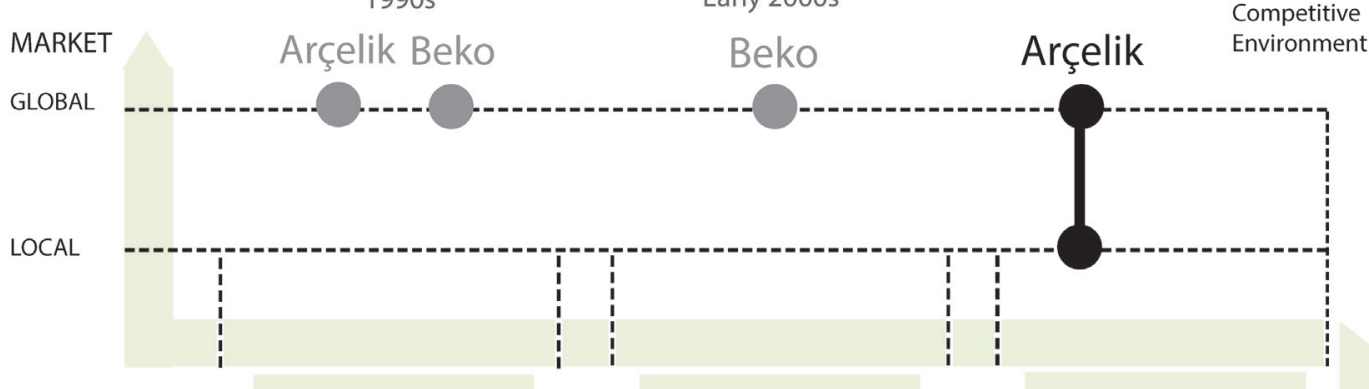

Business Strategies in GVCs

Design Management Capability

Marketing

$R \& D$
OEM

Operational DM

B2B

Tech. Adaptation
ODM

Functional DM

B2B

Tech. Development
OBM

Strategic DM

B2C

Basic Research 


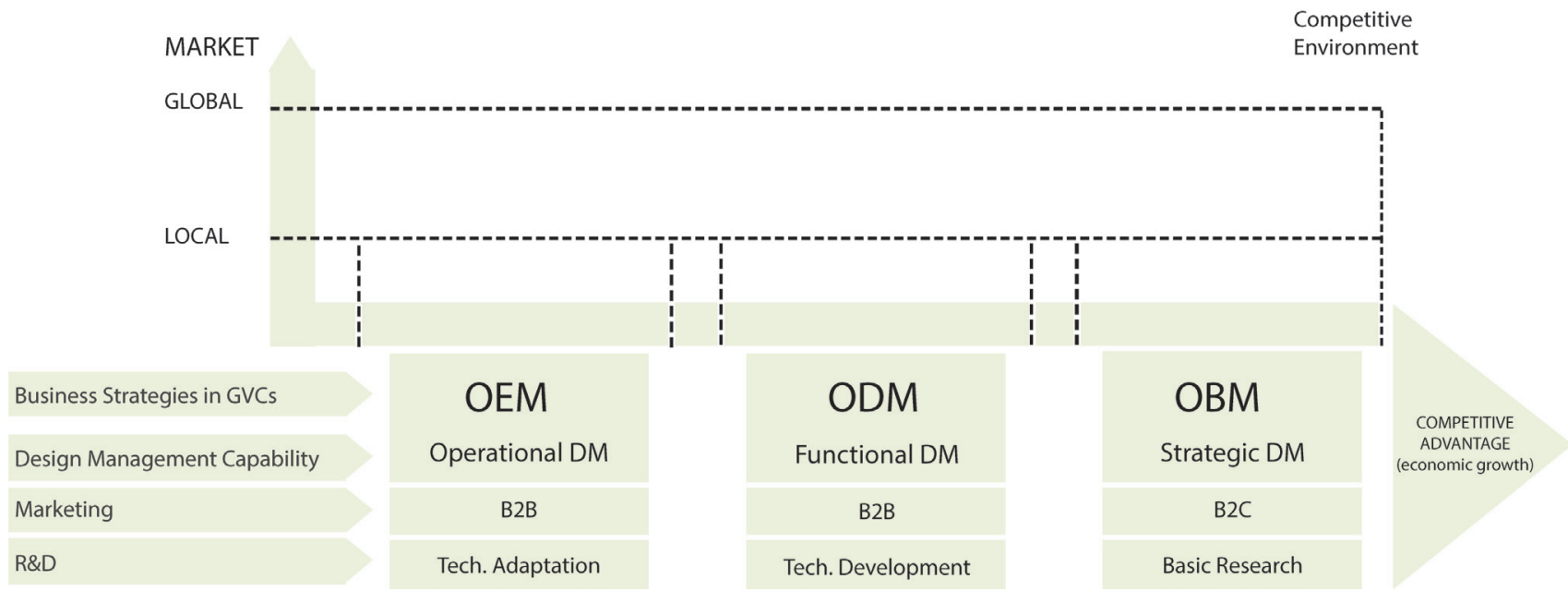

Figure 6. Updated Design Management Capability Framework in GVCs (Manzakoğlu, 2018). circles and they are connected with lines to reflect that they are pursued by the same company. Light grey circles either represent the other but less dominant strategy (Figure 3) or indicate the previous strategies (Figure 5) pursued by the same company.

Consequently, the theoretical framework was revised to indicate different business strategies that might be implemented by the same company simultaneously (Figure 6). Case study findings were summarized in Table 3.

\section{DISCUSSION OF THE FINDINGS}

In this section, each DM capability category identified in Table 3 is discussed comparatively in terms of their changing features through OEMODM-OBM strategies.

\section{a-b) Business Focus and Upgrading in GVCs}

The business focus category, though, represented briefly in the initial theoretical framework (Figure 1), was moved into Table 3 as a separate category since that table was devised as a supplement of the revised framework (Figure 6). Case study findings also revealed the upgrading focus whether it is the process, product, functional, and/or chain/intersectorial upgrading- of each company (Humphrey and Schmidt, 2002).

Termikel case which represents a company pursuing OEM strategy in GVCs focuses on acquiring manufacturing and technological capabilities for improving its products and processes for the local market. Oven R\&D Manager stated that customers bring their own technical knowledge in OEM manufacturing. Hood R\&D Manager (2016) added that "if you manufacture for Franke, they do not directly buy products from you and sell them to the end-user, but send products to China and Germany for comprehensive tests. They then give feedback to us about choosing suppliers, improving products and processes".

Vestel case on the other hand though selected as an ODM reveals a complex profile and uses design capability to increase its market share rather than brand building. It is globally ODM, regionally OBM, and described as "second best in the market" by Vestel Electronics R\&D GM Assistant. 


\begin{tabular}{|c|c|c|c|}
\hline & OEM/Operational DM & ODM/Functional DM & OBM/Strategic DM \\
\hline a) Business Focus & Focus is manufacturing capability. & Focus is design capability. & Focus is image and value creation. \\
\hline b) Upgrading in GVCs & $\begin{array}{l}\text { OEM performs product and } \\
\text { process upgrading by using } \\
\text { design capability. }\end{array}$ & $\begin{array}{l}\text { ODM performs functional upgrading by } \\
\text { adding design function into organization. }\end{array}$ & $\begin{array}{l}\text { OBM performs functional upgrading by adding } \\
\text { marketing and sales function on a global scale. } \\
\text { OBM establishes and governs its own value chain. }\end{array}$ \\
\hline c) Design Awareness & $\begin{array}{l}\text { Design is in top management's } \\
\text { agenda. } \\
\text { Low level of design awareness. } \\
\text { Design as styling }\end{array}$ & $\begin{array}{l}\text { Design is in all employees' agendas. } \\
\text { High-level of design awareness. } \\
\text { In clear and well-planned business } \\
\text { processes design has a defined role. }\end{array}$ & $\begin{array}{l}\text { Design is in all employees' agendas. } \\
\text { High-level of design awareness. } \\
\text { In clear and well-planned business } \\
\text { processes design has a defined role. }\end{array}$ \\
\hline d) Design Capability & $\begin{array}{l}\text { Employment of individual } \\
\text { designers or engineers (silent } \\
\text { design). }\end{array}$ & $\begin{array}{l}\text { a) Selection of designers and formation of a } \\
\text { design team under ID department. } \\
\text { b) ID manages in-house and outsourced } \\
\text { design projects and processes. }\end{array}$ & $\begin{array}{l}\text { a) Establishing design offices on a global scale and } \\
\text { managing them from one center; cooperating } \\
\text { with national and international institutions and } \\
\text { universities. } \\
\text { b) ID manages in-house and outsourced design } \\
\text { projects and processes. }\end{array}$ \\
\hline e) Innovation Drivers & $\begin{array}{l}\text { NPD process starts with a written } \\
\text { order from a customer. } \\
\text { (External: Market) }\end{array}$ & $\begin{array}{l}\text { NPD process starts with a } \\
\text { written order from a customer. } \\
\text { (External: Supplier, technology, market) }\end{array}$ & $\begin{array}{l}\text { NPD process starts with internal decisions. } \\
\text { (Internal: Strategy, design, technology) }\end{array}$ \\
\hline $\begin{array}{l}\text { f) DM at the } \\
\text { Project Level }\end{array}$ & $\begin{array}{l}\text { Product modification and differentia- } \\
\text { tion. } \\
\text { Scope: ID develops 3D drawings, and } \\
\text { builds prototypes for chosen designs, } \\
\text { makes graphic designs on products, } \\
\text { presents designs by using drawings } \\
\text { and prototypes, followed by order } \\
\text { from customer and test production. }\end{array}$ & $\begin{array}{l}\text { - Product differentiation and diversification. } \\
\text { ID department manages its budget. } \\
\text { Scope: ID creates design sketches, full-scale } \\
\text { sD drawings, prototypes, and graphic } \\
\text { designs on products. } \\
\text { Achieves new product time to market and } \\
\text { standardization of quality. }\end{array}$ & $\begin{array}{l}\text { Strategic product design for niche markets and } \\
\text { design innovation. } \\
\text { ID department manages its budget. } \\
\text { Scope: ID uses mood boards and scenario- building } \\
\text { techniques for describing target users across the } \\
\text { organization. In the design process, brand } \\
\text { guidelines, 3D drawings, prototypes, and graphics } \\
\text { designs on products are used systematically. }\end{array}$ \\
\hline $\begin{array}{l}\text { g) DM at the } \\
\text { Organizational Level }\end{array}$ & $\begin{array}{l}\text { R\&D is the responsibility of project } \\
\text { management. } \\
\text { Industrial designers (or engineers) } \\
\text { integrate business processes with } \\
\text { R\&D. } \\
\text { No assignment of ID responsibility } \\
\text { to a manager, instead CEO is } \\
\text { responsible for DM decision }\end{array}$ & $\begin{array}{l}\text { R\&D has the responsibility of project } \\
\text { management. } \\
\text { ID department integrates business processes } \\
\text { with R\&D. } \\
\text { ID increases communication between } \\
\text { manufacturing, R\&D, and marketing. } \\
\text { Assignment of ID responsibility to an ID } \\
\text { manager who has a defined role in the } \\
\text { organization. } \\
\text { Positioning ID at the beginning of NPD. }\end{array}$ & $\begin{array}{l}\text { ID has high-level of effectiveness on project } \\
\text { management and can be the responsibility of } \\
\text { project management depending on project. } \\
\text { ID department integrates business processes with } \\
\text { marketing. } \\
\text { ID performs as catalyst between R\&D and market- } \\
\text { ing. } \\
\text { Assignment of ID responsibility to an ID manager } \\
\text { who has a defined role in the organization. } \\
\text { Positioning ID at the beginning of NPD. }\end{array}$ \\
\hline $\begin{array}{l}\text { h) DM at the } \\
\text { Corporate Level }\end{array}$ & $\begin{array}{l}\text { DM capability is effective on } \\
\text { products. } \\
\text { ID focus is model differentiation, } \\
\text { product modification and } \\
\text { diversification. } \\
\text { OEM acquire technology and } \\
\text { marketing data from customer. } \\
\text { Reverse engineering, cost reduction } \\
\text { and mould developing in R\&D. }\end{array}$ & $\begin{array}{l}\text { DM capability is effective on processes. } \\
\text { ID focuses on increasing competitiveness by } \\
\text { expanding market, performing a high-level } \\
\text { product differentiation, and diversification. } \\
\text { ID manager has direct communication with } \\
\text { top management. } \\
\text { ODM acquires key technology and marketing } \\
\text { data from customer. } \\
\text { ODM develops and produces new designs for } \\
\text { its customers. }\end{array}$ & $\begin{array}{l}\text { DM capability is effective on strategy. } \\
\text { ID focuses on creating original product strategies } \\
\text { and supporting brand value. } \\
\text { ID manager has direct communication with top } \\
\text { management. } \\
\text { OBM places innovation as a core value at the center } \\
\text { of the business strategy and organizational } \\
\text { structure. } \\
\text { Development of an integrated approach between } \\
\text { DM strategy, brand strategy, corporate identity, } \\
\text { manufacturing, and R\&D. Existence of design } \\
\text { guidelines and standards for each brand. }\end{array}$ \\
\hline i) User Research & $\begin{array}{l}\text { No user research } \\
\text { B2B business }\end{array}$ & $\begin{array}{l}\text { No user research } \\
\text { B2B business }\end{array}$ & $\begin{array}{l}\text { User research at the beginning and end of the } \\
\text { NPD process (in ID, R\&D, and marketing } \\
\text { departments). } \\
\text { Sources: Exhibitions, surveys, consultancies, } \\
\text { suppliers, distributors, business reports, focus } \\
\text { group research, lead user research, ethnographic } \\
\text { research. }\end{array}$ \\
\hline
\end{tabular}

Table 3. DM capabilities in relation to OEM-ODM-OBM positioning in GVCs (Manzakoğlu, 2018).
According to him, as a company with high production volume, their goal is "to make the best product time to market by filling production lines". 
Arçelik case as an OBM company reveals that the company has been reinforcing its local and global brands since the early 2000s, and performed functional upgrading by adding marketing and sales function on a global scale. In this context, the design function has evolved the strategic aim of reflecting different brand values in all products ranges. The Product Sourcing R\&D Manager explained that ID Directory and Brand Management have an intimate collaboration in forming brand guidelines: "The values represented by our brands in these books and the contribution of design in creating these values are known by all directories in the company". As an OBM company, Arçelik, establishes and governs its own value chain, designs new products, defines its standards, and contracts its production to other OEM companies for production, and sells them to end customers with its own brands on a global scale.-

\section{c) Design Awareness}

For Storvang et al. (2014), awareness is used as a parameter to reveal the design thinkers within a company. In the OEM case, design is found to be important in top management's agenda for specific projects to meet the needs of OBM customers and considered as styling in the organization, exemplified by a statement from the Oven R\&D Manager: "If there are sufficient technical resources inside the organization, you can shape everything and this is already design". Design awareness is found as low (scoring 2) because the institutional structure that facilitates general planning and supports design awareness and culture is under development.

In the ODM case, design is found to be important in all employees' agenda and the Design Atlas audit responses indicate that Vestel has a high level of design awareness (scoring 4) since it shares all its plans and clearly defined objectives with employees through SPI (schedule performance index), regular meetings, and written reports published regularly. As a result of high-level communication inside the organization, R\&D and marketing have high-level design awareness, summarized by Vestel Marketing, TV Brand Manager (2016) as "everything starts with design in our company... ID is involved in the NPD process before the baby is born... ID is at the beginning of the NPD process".

In the OBM case, design is found to be important in all employees' agenda and Design Atlas audit results indicate that Arçelik has high-level of design awareness (scoring 4). In the clear and well-planned organizational processes of Arçelik; ID, marketing, and R\&D have used a common platform system/network for sharing the five-year-long planning processes, in which design has a well-defined role. The Small Appliances Marketing Manager stated that this platform system enables knowledge accumulation and is also used as a source for developing new ideas, concepts and gathering information from a variety of sources.

\section{d) Design Capability}

Finding out where design capability originates in the company and examining what design skills are available internally is significant for exploring the scope of DM capability (Storvang et al., 2014; Santos et al., 2018). In the OEM company, industrial Design (ID) activities are assigned to six of the eighteen engineers in the oven, hood, and hob R\&D departments; in other words, the required design input for OEM strategy can be obtained from individuals such as industrial designers, engineers or technicians. 
The ODM company has two ID departments under two divisions: Vestel Electronics has twenty employees and Vestel White-goods has fourteen employees. Both companies support in-house design by taking and managing to outsource design activities from reputed local and global design offices and also cooperate with universities. Vestel Electronics ID Manager stated; "We manage all relationships with external design consultancies and universities. Our philosophy here is mainly to feed design culture within the company". However, although ID departments of electronics and white-goods divisions are located in the same facility, there is a communication gap between them explained by Vestel Electronics' Senior Industrial Designer with the phrase: "No one asked us to set up an orchestra". Although the design skills of Vestel, seem to be well-developed, it can be concluded that pursuing ODM strategy led to a lack of focus on design language coherency required for brand building.

In the OBM company, ID responsibility is assigned to an ID director who has direct communication with top management and manages thirty employees. While the focus of the company is brand image and value creation by supporting innovation in the organization, ID focuses on creating original product strategies towards new niche markets; manages all in-house design offices located in different countries (for example, China), and outsources design activities to various consultancy companies from one center. It is apparent that the aim is to align design capabilities with the brand-building strategy.

\section{e) Innovation Drivers}

Design can be a driver of innovation (Verganti, 2008) in addition to technology, market, and suppliers as innovation drivers. The main drivers of innovation through OEM-ODM-OBM strategies reveal the linkage between business strategies and DM capability levels.

In the OEM company, all interviewees emphasized external factors such as OBM customers and market as the source of innovation.

In the ODM company, Vestel Electronics R\&D GM Assistant and Vestel Electronics Marketing GM Assistant identified external factors as technology \& suppliers as the main driver of innovation, Vestel Electronics ID Manager opted for market and Vestel White-goods ID Manager picked technology. Since big suppliers develop new technologies for TVs and the electronics industry, they dominate and lead the market.

In the OBM company, while the ID Director and the industrial designer interviewed put design \& technology first, the Small Appliances Marketing Manager added business strategy and the Product Sourcing R\&D Manager chose technology and market. Ali Koç, Koç Holding's Chairman of the Board, confirmed that: "Today, the concept of innovation in Arçelik is integrated with the corporate culture and daily life, starting from the top management of the company to all departments and even to sales units that are in direct communication with the consumer" (2015). It can be concluded that innovation is at the heart of the company's business strategy and internal dynamics trigger innovation processes.

\section{f) DM at the Project Level}

The project level of DM focuses on how the design process is conducted in relation to business strategy by questioning design competencies, company's goals towards design projects, selection of designers, design briefs, and design policies (Borja de Mozota, 2003). In the OEM strategy 
case, the focus of design processes is found to be product differentiation. The GM Assistant described the NPD in following OEM strategy as follows; "Design starts with a written brief from the customer. If the customer demands a new product, then the designer gets involved in the process. Customers refer to similar products in the market. Then we begin the NPD process by disassembling the rival products. After defining its specifications and creating a new design, we send renders generated from $3 \mathrm{D}$ drawings. A prototype of the chosen design is used to develop the product before trial production".

In the ODM company, the ID function can achieve high-level diversification between products and has a significant role in differentiating 144 brands by strengthening the ODM strategy. According to Vestel Electronics R\&D GM Assistant, "All customers are differentiated by $10-20 \%$ on the production platform. When you look inside the remote controls of A-brands such as Toshiba, Panasonic, Medion, etc. you will see all of them are Vestel". According to the Vestel Electronics ID Manager, "Design process begins with clear written briefs from product managers. Then we develop new ideas and define a product strategy. In addition to product design activities, such as design sketches, 3D drawings, prototype building, graphic designs on products, etc. we take responsibility for designing exhibition stands, packaging, product catalogues, and photographing products in our in-house studio". In Vestel Electronics and White-goods, ID departments have their budget, manage their in-house and outsource design activities and their products regularly receive international awards.

In the OBM company (Arçelik), strategic product design activities and innovative designs have been developed for niche markets, for example, a refrigerator design with rice storage for China, a pizza oven for Italy, a solar-powered refrigerator for non-electric using regions of South Africa. The ID Director explained how they approach NPD; "We can benefit from different industries, materials or production techniques. Therefore, we are in a position to direct $R \& D$ and manufacturing teams towards different applications on existing systems. We aim to propose future products of our brands and to differentiate in the market with innovative leadership", and added; "For in-house presentations, the design team prepares mood boards describing the target user. The whole process is transformed into designing an emotional product together with fiction, scenario building, gaining customer insight and designing a different user experience towards the target group". The Industrial Designer interviewee emphasized the open communication channels in the design process: "At the initial stages, we share our work with the mechanical design teams to discuss technical capabilities, then we present the developed concept to marketing and top management with prototypes and renders of 3D drawings". The use of mood boards in ID presentations and the development of brand guidelines were identified as the significant enablers of design culture within the company.

\section{g) DM at the Organizational Level}

$\mathrm{DM}$ at the organizational level focuses on the integration of design into organizational processes such as coordination of design strategy and process with other functions, tasks, and roles of design manager, the position of design function in the organization (Borja de Mozota, 2003). In the OEM company's organizational structure, the R\&D department is responsible for ID activities and management of the NPD processes. The Marketing Manager stated that "the lack of industrial designers or product 
managers leads to a lack of communication between R\&D and marketing. Product development activities have been conducted without marketing data". Top management is responsible for making design decisions.

In the ODM company, having integrated organizational processes with $R \& D$, industrial designers can join multiple cross-functional teams in the matrix organizational structure under the leadership of product managers who directly report to the R\&D General Manager. That structure enables high-level communication between business functions. "When a customer comes to Vestel, s/he doesn't see products already sold to another OBM customer, thanks to the system that we structured. This allocation system and showrooms provide a high level of dependency on us for Marketing, Product Management and Foreign Trade" (Vestel Electronics Senior Industrial Designer). This role of ID in differentiating products and reinforcing the ODM strategy occurred due to the complex allocation list on display and the big showrooms, all resulting in high-level communication between business functions.

In the OBM company, the ID Department was positioned under the Marketing General Manager in 2016 and is demonstrably effective in global brand strategy as well as project management processes. Industrial designers are integrated into the matrix organizational structure with cross-functional teams to serve multiple products and brands of Arçelik. ID provides high-level communication between $R \& D$, marketing, and manufacturing functions.

OEM-ODM-OBM strategies bring about different organizational structures in which industrial design has different positions aligning with the business objectives. In functional upgrading from OEM to ODM, design becomes a department and in our research, it was found to be positioned under R\&D.

To sum up, pursuing an ODM strategy for many years in GVCs was found to be a barrier for the transformation of an organization to a design and brand-focused company from a manufacturing one. In particular, B2B business model limits the strategic DM capability of a company as it requires production capability rather than brand building.

\section{h) DM at the Corporate Level}

Corporate level DM focuses on the DM responsibility of top management, design strategy within the context of business strategy, defining design standards in all communication channels such as product, graphic, space, communication, and information designs (Borja de Mozota, 2003).

In the OEM company case, the CEO is responsible for all kinds of decisionmaking. Hence, according to the Marketing Manager, completing the transition to an institutional organization must be their priority.

In the ODM company, Vestel Electronics ID Manager directly presents new designs to the Chairman of the Board, though the ID Department itself is positioned under the R\&D Assistant General Manager. "If the design is not supported by top management", explained the Vestel Electronics ID Manager, "it can remain naïve in this large-scale engineering dominated organization". It is apparent that since the organizational structure mainly reinforces the ODM strategy, the design function needs to be supported by top management personally. 
Additionally, interviewees explained that Vestel branded products have been chosen from the product pool in the showroom, developed for OBM customers. Therefore, it was concluded that the company has no awareness of the importance of establishing a consistent product language within its product range. The lack of brand-building orientation is found to be the reason for the shortage of a consistent product design language in companies following OEM and ODM strategies.

In the OBM company, design management is aligned with the multiple brand strategy that they have been following in GVCs. The ID Director stated that design was appropriated throughout the organisation, giving the example that sales, marketing, product sourcing, and product management were all involved in defining a two-year colour palette: "In the last four years, we have focused on designing new experiences and developing design languages on products to align product and brand values. Our new approach is supported at CEO level in our innovative organizational culture".

\section{i) User Research}

User research becomes central to product development, in relation to design and provides input to the design process. In OEM and ODM companies, the lack of user research was identified as the most neglected capability due to embracing B2B marketing. The OEM company's Oven R\&D Manager stated that "since technical specifications, rules, marketing, and user data are obtained from OBM customers and dealers, we don't need to do user research in OEM... in OBM projects we obtain market data from our dealers, exhibitions, competitors and trade partners."

In the OBM company, the ID, marketing, and R\&D teams conduct their own user research in the NPD process. As explained by the ID Director: "Especially, in Turkey and Europe, user scenarios are created with the information gathered from user research. During the UK home visits (2008-2009), permission was obtained to record (video) users. This research resulted in five patents... when we entered the US market, initially the ID Department received information from retailers, then we conducted comprehensive ethnographic research comprising of fourteen home visits to observe the existing products, their arrangement in the home, and usage habits of lead users. That knowledge leads the design process...". Active participation of designers in the user research was defined as the most impactful factor in the design process because of its contribution to designers' collaborative learning about users (Oygür and Thompson, 2020).

The main difference between DM capabilities of OEM-ODM-OBM strategies was identified as implementing user research methods that serve to build up design mindset across the organization and develop a collective organizational capability follow niche market strategies in international markets and establish visual coherency among all products and communication means by using brand guideline books.

\section{Barriers to the DM Capability}

This category reveals the main barriers toward using strategic level DM capability in OEM-ODM-OBM strategies. In the OEM and ODM companies, the lack of OBM orientation is found to be a significant barrier to the strategic level of DM. In the ODM company, major barriers to the strategic use of design within the ODM strategy are found as technology dependency, domination of engineering culture, and large-scale 
manufacturing. According to the interviewees, the strength of strategic DM capability in the OBM company was affected by large-scale manufacturing, domination of engineering culture, and technology-oriented sector dynamics.

\section{CONCLUSIONS}

This article explores the linkage between the business strategies followed in GVCs by latecomer companies and their DM capabilities. The different industrial development paths, especially the GVC-oriented industrialization of latecomers with particular reference to functional upgrading is neglected in the DM literature (Manzakoğlu and Er, 2018). Therefore, we aimed to fulfil this gap by testing the Design Management Capability Framework in GVCs through three case studies specifically selected from an emerging market as representative companies following OEM-ODM-OBM strategies and positioning themselves as such in GVCs. With this study, we have tested the validity of the framework with data obtained from the electrical and electronics industry in Turkey. The context-specific data from three case studies is a limitation of this study. Further studies in other industries and in other countries which followed the path of latecomer industrialization can contribute to the connection of DM literature with the theory of industrial development based on technology transfer and positioning in GVCs.

The prevailing features of the operational-functional-strategic level of design management capabilities in the OEM-ODM-OBM strategies were formed as a checklist (Table 3) by analysing the findings in key categories of inquiry undertaken in the case studies. These features also form the basics of a potential self-assessment tool as other companies would also be able to position themselves on the framework regarding the strategies they follow in local and global markets (Figure 6). The outputs of this study can be used to identify deficiencies in DM capabilities and also opportunities for business strategy improvement.

Design has been accepted as a core innovation activity in Oslo Manual 2018 and defined as a business capability with an emphasis on its' three significant aspects; product design, engineering design, and design thinking (OECD/Eurostat, 2018). The Manual also suggests companies use the Danish Design Ladder to investigate the integration level of design capability into management processes (Danish Business Authority, 2008). However, the Danish Design Center's Design Ladder model does not make a connection between DM levels and business strategies in GVCs (Manzakoğlu and Er, 2018). Therefore, we put forward a new conceptual model as Design Management Capability Framework in GVCs for latecomer companies and used the Design Capacity Model created as a theoretical supplement of Danish Design Ladder in developing our categories of inquiry (Storvang et al., 2014).

Assessing the DM capability level of a company is significant in identifying and fulfilling the gap between existing and desired business performance. Hence, this study puts forward a holistic view on how DM capability, other firm capabilities, and business strategies are connected and dependent on each other. Case studies showed that the selected business strategy of a company in a specific market defines and sometimes limits the scope of DM capability despite its possession at the highest level by that company as in the case of ODM company. 
Since the case studies in this article were carried out in 2016 in the Ph.D. study, we reviewed the current state of the selected companies. While the OBM and ODM company cases continue to possess their large-scale exporters status, the OEM company is found to be reduced its production volume and business capacity (Cumhuriyet, 2021). This may be an indication of the importance of achieving functional upgrading and capability building in GVCs as following an OEM strategy as a low-cost manufacturer appears to be an unstable position for latecomer companies.

\section{REFERENCES}

ACKLIN, C. (2013) Design Management Absorption Model: A Framework to Describe and Measure the Absorption Process of Design Knowledge by SMEs with Little or no Prior Design Experience, Creativity and Innovation Management 22(2) 147-60.

AFUAH, A. (2002) Mapping Technological Capabilities into Product Markets and Competitive Advantage: The Case of Cholesterol Drugs, Strategic Management Journal 23(2) 171-79.

Arçelik Global (2016) Faaliyet Raporu [https://www.arcelikglobal.com/ tr/sirket/raporlar-ve-sunumlar/incele/?val=3745] Access date (20.12.2017).

BORJA DE MOZOTA, B. (2003) Design Management: Using Design to Build Brand Value and Corporate Innovation, New York: Allworth Press.

CHUNG, K. W. (1998) The Nature of Design Management: Developing a Curriculum Model, Design Management Journal 9(3) 66-71.

COOPER, R., PRESS, M. (1995) A Guide to Successful Design Management: The Design Agenda, John Wiley \& Sons, Chichester.

CUMHURİYET (2021) Mali Krizi Aşamadı: İhracat Devi Termikel'in Fabrikası Satıliyor (12.02.2021). [https://www.cumhuriyet.com. tr/haber/mali-krizi-asamadi-ihracat-devi-termikelin-fabrikasisatiliyor-1813326] Access date (18.10.2021).

DANISH BUSINESS AUTHORITY (2008) Erhvervs-og Byggestyrelsen. Design skaber værdi-udbredelse og effekter af design. København, Denmark.

DESIGN COUNCIL (1999) Design Atlas: A Tool for Auditing Design Capability, British Council.

DIPPOLITO, B. (2014) The Importance of Design for Firms Competitiveness: A Review of the Literature, Technovation 34(11) 71630.

EASTON, G. (2010) Critical Realism in Case Study Research, Industrial Marketing Management 39(1) 118-28.

EFQM (1995) Self Assessment Guidelines. European Foundation for Quality Managements, Brussel.

ERNST, D. (2008). Asia's ‘Upgrading through Innovation' Strategies and Global Innovation Networks: An Extension of Sanjaya Lall's Research Agenda. Transnational Corporations 17(3) 31.

FERNÁNDEZ-MESA, A., ALEGRE-VIDAL, J., CHIVA-GÓMEZ, R., GUTIÉRREZ-GRACIA, A. (2013) Design Management Capability and Product Innovation in SMEs, Management Decision 51(3) 547-65. 
GEREFFI, G., FERNANDEZ-STARK, K. (2011) Global Value Chain Analysis: A Primer, North Carolina: Duke University, Center on Globalization, Governance \& Competitiveness.

GEREFFI, G., STURGEON, T. (2013) Global Value Chain-Oriented Industrial Policy: The Role of Emerging Economies. In Global Value Chains in a Changing World, edited by D. K. Elms and P. Low, Geneva,World Trade Organization; 329-60.

HKTDC (2008) Study on OEM, ODM and OBM: Extending the Supply Chain with Added Value. Hong Kong.

HOBDAY, M. (1995) East Asian Latecomer Firms: Learning the Technology of Electronics, World Development 23(7) 1171-93.

HUMPHREY, J., H. SCHMIDT. (2002) How Does Insertion in Global Value Chains Affect Upgrading in Industrial Clusters? Regional Studies 36(9) 1017-27.

KOÇ, A. (2015) Sözde Değil Özde Inovasyon (Innovation at the Core, not Socalled), in How Family Businesses be Innovative? Swiss Turkish Economic Forum, Koç University Graduate School of Business, 6-9. [http://www.tr-ch.org/wp-content/uploads/2015/11/SwissTurkish_ Matbaa.pdf] Access date (13.11.2016).

KOTLER, P., RATH, G. A. (1984) Design: A Powerful but Neglected Strategic Tool, Journal of Business Strategy 5(2) 16-21.

KOOTSTRA, G. L. (2009) The Incorporation of Design Management in Today's Business Practices: An Analysis of Design Management Practices in Europe, Europe: Design Management, ADMIRE Programme.

MANZAKOĞLU, B.T. (2018) The Relations Between Upgrading Strategies in Global Value Chains and Design Management Capabilities: An Investigation on Firms Operating in Turkish Electrical and Electronics Sector, unpublished PhD dissertation, Graduate School of Science Engineering and Technology, Istanbul Technical University.

MANZAKOĞLU, B. T., ER., Ö. (2018) Design management capability framework in global value chains: Integrating the functional upgrading theory from OEM to ODM and OBM, The Design Journal 21(1) 139-61.

MUTANEN, U-M. (2008) Developing Organizational Design Capability in a Finland- Based Engineering Corporation: The case of Metso, Design Studies (29) 500-20.

OECD (2012) Mapping Global Value Chains. Organisation for Economic Cooperation and Development (OECD). [http://www.oecd.org/dac/aft/ MappingGlobalValueChains_web_usb.pdf/] Access date (20.12.2017).

OYGÜR, I., THOMPSON, J. A. A. (2020) Intra-organizational user-centred design practices: The impact of design research departments at design consultancies, Creativity and Innovation Management 29(1), 112-7.

SANTOS, R. DOS, BUENO, E. V., KATO, H. T., CORRÊA, R. O. (2018) Design Management as Dynamic Capabilities: A Historiographical Analysis, European Business Review 30(6) 707-19. 
STORVANG, P., JENSEN, S., CHRISTENSEN., P. R. (2014) Innovation Through Design: A Framework for Design Capacity in a Danish Context, Design Management Journal 9(1) 9-22.

TAYMAZ, E., YILMAZ., K. (2008) Integration with the Global Economy: The Case of Turkish Automobile and Consumer Electronics Industries, Working Paper No.37, The International Bank for Reconstruction and Development, Washington.

Turkish Exporters Assembly (2016) 2016 Export Values on a Sectoral Basis. [https://www.tim.org.tr/tr/raporlar-ilk-1000-ihracatci-arastirmasidosyalar-2016] Access date (4.12.2016).

TOPALIAN, A. (1990) Developing a Corporate Approach, in Design Management: A Handbook of Issues and Methods, edited by M. Oakley, Oxford, Blackwell; 117-27.

VERGANTI, R. (2008) Design, Meanings, and Radical Innovation: A Meta-Model and a Research Agenda, Journal of Product Innovation Management 25 436-56.

Vestel Yatırımcı İlişkileri (2016) Vestel Elektronik 2016 Faaliyet Raporu [http://www.vestelyatirimciiliskileri.com/_assets/pdf/faliyet/2016/ faaliyet-raporu-2016.pdf] Access date (13.12.2017).

WALSH, V., ROY, R., BRUCE, M., POTTER., S. (1992) Winning by Design, Blackwell Business, Oxford.

WEERAWARDENA, J. (2003) The Role of Marketing Capability in Innovation-Based Competitive Strategy, Journal of Strategic Marketing 11(1) 15-35.

WESTCOTT, M., SATO, S., MRAZEK, D., WALLANCE, R., VANKA, S., BILSON, C., HARDIN, D. (2014) The DMI Design Value Scorecard: A New Design Measurement and Management Model, Design Management Review 24(4) 10-6.

YIN, R. K. (2014) Case Study Research: Design and methods, 5th ed., Sage Publications, California, Los Angeles.

Alındı: 12.05.2021; Son Metin: 31.12.2021

Anahtar Sözcükler: Tasarım yönetimi kabiliyeti; fonksiyonel yükselme; geriden gelen firmalar; küresel değer zincirleri; firma stratejisi.

\section{KÜRESEL DEĞER ZINCİRLERINDE FARKLI FIRMA STRATEJILERI IZLEYEN FİRMALARIN PERSPEKTİFINDEN TASARIM YÖNETIMİ KABİLIYYETİ DEĞERLENDİRMESI}

Tasarım yönetimi, küresel pazarlarda rekabet avantajı elde etmek için gerekli olan stratejik bir firma kabiliyetidir. Bu nedenle, firmaların tasarım yönetimini organizasyonlarına entegre etmelerine rehberlik etmek için çok sayıda model ve çerçeve ortaya konmuştur. Bu çalışmalar aynı zamanda tasarımın daha iyi kullanımı, organizasyonel stratejiye ve firma işlevlerine entegrasyonu, dolayısıyla daha iyi bir tasarım yönetimi için firmalara yol haritası sağlamaktadır.

Gelişmekte olan ekonomilerde faaliyet gösteren geriden gelen firmalar (latecomer firms-LCFs), tasarım yönetimi kabiliyetlerini teknolojik ve üretim kabiliyetleriyle birlikte geliştirmektedir. Bu sebeple, tasarım yönetiminin seviyesi ve kullanımı o firmanın küresel değer zincirlerinde 
(Global Value Chains-GVCs) izlediği firma stratejilerine (OEM-ODM-OBM) bağlidır.

Odaklanmış bir literatür araştırmasına dayanarak, tasarım yönetimi kabiliyeti ve geriden gelen firmaların küresel değer zincirlerinde izledikleri belirli iş stratejileri arasında bağlantı kuran, dolayısıyla tasarım yönetimi literatüründe bir boşluğu dolduran yeni bir çerçeve geliştirildi. Küresel Değer Zincirlerinde Tasarım Yönetimi Kabiliyeti Çerçevesi kullanılarak, OEM-ODM-OBM stratejileriyle tasarım yönetimi kabiliyeti arasındaki ilişkiyi araştırmak amacıyla Türk Elektrik Elektronik Sektörü'nde faaliyet gösteren üç firma vaka çalışması için seçildi. Bu şekilde kavramsal çerçeve vaka çalışmaları yapılarak test edildi. Vaka çalışmalarının bulguları tasarım yönetimi kabiliyeti, diğer firma kabiliyetleri ve firma stratejilerinin birbirlerine ne kadar bağlı olduğunu gösterdi. Buna ek olarak, üretici firmaların tasarım yönetimi kabiliyetlerindeki eksiklikleri ve firma stratejisi geliştirmek için yaratabilecekleri fırsatları belirlemede kullanılabilecekleri bir öz değerlendirme aracının temellerini ortaya koydu.

\section{DESIGN MANAGEMENT CAPABILITY ASSESSMENT FROM THE PERSPECTIVE OF COMPANIES PURSUING DIFFERENT BUSINESS STRATEGIES IN GLOBAL VALUE CHAINS (1)}

Design management (DM) is a strategic business capability to gain competitive advantage in the global market. To guide companies to integrate DM into their organizations, a multitude of diagnostic frameworks and tools were put forward. These studies also provide pathways for better use of design and its integration into organizational strategy and functions, hence for better DM.

Operating in emerging economies, latecomer firms (LCFs) develop their DM capability along with their technological and manufacturing capabilities, and therefore its level and usage are dependent on the business strategies (OEM-ODM-OBM) that they follow in Global Value Chains (GVCs).

Based on a focused literature review, a new framework has been put forward to establish a linkage between DM capability and specific business strategies followed by LCFs to take a position in GVCs, thus fulfilling a gap in the DM literature. Three case studies selected from the Turkish electrical and electronics industry were undertaken with the aim of investigating the nature of DM capability in relation to OEM, ODM, and OBM strategies by using the Design Management Capability Framework in GVCs. Thus the conceptual framework was put to test through the case studies. Case study findings indicated how DM capability, other firm capabilities, and business strategies are dependent on each other and featured the basics of a potential self-assessment tool to be used to identify deficiencies in DM capabilities and opportunities for business strategy improvement.

BİLGEN TUNÇER MANZAKOĞLU; B. ID, M.Sc., PhD.

Received her bachelor's, master's and $\mathrm{PhD}$. degrees in industrial design from Istanbul Technical University (ITU), Faculty of Architecture. Major research interests include various patterns of design management capability development in GVCs, strategic use of design and design audits and practice theory. bilgen.manzakoglu@arc.bau.edu.tr

ÖZLEM ER; B. ID, M.Sc., PhD.

Received her bachelor's and master's degrees in industrial design from Middle East Technical University (METU). Earned her PhD. degree from the Institute of Advanced Studies at Manchester Metropolitan University, UK. Major research interests include design management, strategic design, design research methods and industrial design education. ozlem.er@bilgi.edu.tr 
